\title{
UNDERSTANDING BEHAVIOR OF DIGITAL MONEY APPLICATION USAGE ON ADOLESCENTS
}

\author{
Yeyen Pratika \\ Faculty of Economics and Business, Universitas Muhammadiyah Malang, Indonesia \\ Email:yeyenpratika@umm.ac.id
}

\begin{abstract}
Information technology has changed the existing transaction process from manual to digital-based. The presence of financial technology, especially digital money drives to the high competition. Companies apply various marketing strategies to win the market competition. The mechanism of cashback promotion is mostly provided by digital money companies as their marketing strategies to attract customers. Cashback promotion program triggers a change of customer behavior to use digital money due to cashback promotion. This study aims to examine the factors that influence the use of digital money application on adolescents by using hedonic and utilitarian motivation, behavior aspect, intention to use and usage behavior. This studies used path analysis by utilizing the SmartPLS program. This study involved 113 respondents who have digital money application on their smartphone. The result found that hedonic motivation, utilitarian motivation and behavior aspect have a positive effect on the intention of use. In addition, intention of use also has a positive influence on usage behavior.
\end{abstract}

Keywords: digital money, hedonic and utilitarian motivation, behavior aspect, intention of use, cashback promotion

\section{Introduction}

The development of information and communication technology has changed the traditional transaction process. Bank Indonesia (BI) noted that electronic money transaction reached by IDR 5.19 million in the end of 2018 or increased around $33.72 \%$ from the previous year. It is noted that this increasing occurred due to the increasing of the usage of electronic money on online transaction, especially on e-commerce and e-toll transaction.

The increasing in digital money is driven by government support through the regulation of Bank Indonesia in creating cashless society that can accommodate the development of financial technology (fintech). Fintech is defined as the efficiency of financial or banking services by utilizing technology (Fajrina, 2016) Various fintech applications appear as payment method and also loan. Rachman (2016) mentioned that there are 9 categories of fintech which are capital market, financial service product, payment, loan, mortgage, internet banking, financial planning, reward and donation and digital money. A variety of digital money applications have emerged to meet the needs of people who increasingly lead to the digital era.

This category of digital money is a non-cash payment instrument that utilizes electronic devices including smartphone. The emergence of various digital money application is fostering high competition so that digital money application companies use many marketing strategies to attract consumers, one of them is by using cashback promotion. Ballestar, Garu- 
International Journal of Economics, Business and Accounting Research (IJEBAR)

Peer Reviewed - International Journal

Vol-4, Issue-1, 2020 (IJEBAR)

E-ISSN: 2614-1280 P-ISSN 2622-4771

https://jurnal.stie-aas.ac.id/index.php/IJEBAR

Carles, \& Sainz (2016) stated that cashback promotion grows significantly as a marketing instrument that can change traditional cashback (rebate) transaction by utilizing internet services. This argument is also supported by the report conducted by Nielsen (2016) which found that giving rewards in the form of cashback ranks as the top of the market needs for companies to attract consumers. The findings show that cashback is good alternative marketing strategy to attract consumers to use the digital applications offered.

In Indonesia, Lestari, Arsilan, \& Rachman (2019) stated that Gopay and OVO are the market leaders in digital money which triggered quite high competition in terms of cashback promotions. This becomes more interesting when the cashback program encourages changes in consumer behavior in terms of purchasing decisions. Previous research is limited to cashback strategies in influencing consumer behavior (Christino, Silva, Cardozo, de Pádua Carrieri, \& de Paiva Nunes, 2019). Research on the phenomenon of cashback on digital money applications is still limited, so this study aims to analyze the factors that influence the behavior of using digital money applications in adolescents as a result of the cashback program.

Based on this description, the problem examined in this study relates to the behavior of using digital money applications in adolescents. Several previous studies have examined a lot about the intention to use, however, not many studies have examined the behavior of using digital money applications in adolescents, especially those triggered by marketing strategies in the form of cashback.

\section{Literature Review}

Technological developments encourage the increasing in online shopping activities. This indicates that online shopping has become a habit for most consumers so that companies need to apply various strategies to increase promotion and distribution of products and services (Zhou, Cao, Tang, \& Zhou, 2017). The emergence of various online shopping applications motivates companies to win the attention of consumers by adopting various marketing methods, one of which is the cashback program. Cashback is an offer in which the buyer is given a percentage of a cash or digital refund by meeting certain purchase conditions specified by the organizer.

Jayabuana (2018) said that the results of a survey conducted by Shopback showed that there was an increase in the volume of online transactions in the community triggered by various promos, cashback, and loyalty programs offered by the company. Furthermore, the results of this survey also show that various digital payment instruments applications in Indonesia utilize cashback to attract consumers. This is proven by $51.6 \%$ of respondents consisting of 5,600 respondents who stated using the digital money application during the cashback promo. In addition, the survey results also showed that GO-PAY and OVO were the most widely used applications, namely $41.6 \%$ and $29.7 \%$.

\section{Hedonic and Utilitarian Motivation, Intention to Use}

Ding \& Tseng (2015) explained that hedonic features are generated by intrinsic motivation such as recreational activities, aesthetic appreciation, games and creativity. In line with this explanation, To, Liao, \& Lin (2007) also mentioned that the benefits of hedonic motivation are experiences and emotional where it is formed because hedonic motivation refers to consumption behavior in seeking happiness, fantasy, enlightenment, sensuality and enjoyment. In addition, multisensory and fantasy responses are related to the user's hedonic 
International Journal of Economics, Business and Accounting Research (IJEBAR)

Peer Reviewed - International Journal

Vol-4, Issue-1, 2020 (IJEBAR)

E-ISSN: 2614-1280 P-ISSN 2622-4771

https://jurnal.stie-aas.ac.id/index.php/IJEBAR

emotions.

In Unified Theory of Acceptance and Use of Technology 2 (UTAUT2) developed by Venkatesh, Thong, \& Xu (2016) showed that hedonic motivation is one of the constructs underlying individuals receiving and using new technology. Anderson, Knight, Pookulangara, \& Josiam (2014) revealed that the use of technology can encourage feelings of pleasure that make consumers perceive shopping as something fun. In their research on cashback sites, Christino, Silva, Cardozo, de Pádua Carrieri, \& de Paiva Nunes (2019) found that consumers who took advantage of the cashback program believed the sense of pleasure felt influenced him to use the site.

Furthermore, utilitarian motivation reflects overall consumer ratings of functional benefits and sacrifice (Overby \& Lee, 2006). This is in line with Okada (2005) who revealed that utilitarian refers to the actions taken by consumers to maximize existing utilities. So, from this perspective the customer uses a product because of the benefits that will be obtained. The benefits intended here also include comfort (Zeithaml, Parasuraman, \& Malhotra, 2002).

In the study conducted by Scholl-Grissemann \& Schnurr (2016) stated that to provide the best experience for consumers, companies need to know how hedonic and utilitarian solutions can influence the high reaction and stimulus in using these products. The combination of hedonic and utilitarian performance will be more visible in mobile shopping services such as when consumers of mobile devices not only aim to obtain information about a product or service (utilitarian) but also for pleasure (hedonic) when using various electronic device functions (Bilgihan \& Bujisic, 2015). Thus, the hypotheses in this study are as follows:

H1: Hedonic motivation has a positive influence on intention to use

H2: Utilitarial motivation has a positive influence on intention to use

\section{Behavioral Aspect and Intention to Use}

Morgan \& Hunt (1994) mentioned that to create a successful relationship in marketing, the existence of a marketing relationship and trust is the main key because it directly leads to cooperative behavior. In this study, behavioral aspects refer to the extent to which the use of technology will be able to influence the buying behavior of consumers and users (Vana, Lambrecht, \& Bertini, 2018).

The study conducted by Lissitsa \& Kol (2016) found that millennial generation is the first generation to grow with digital technology which makes this generation very adept in using technology and more involved in online behavior. However, Christino, Silva, Cardozo, de Pádua Carrieri, \& de Paiva Nunes (2019) suggested in that behavioral aspects do not show has no significant influence on the intention to use. Furthermore, the significant influence of behavioral intentions on adoption behavior indicates that consumers are willing to adopt cashback programs that have the potential to attract attention. For this reason, the following hypothesis is proposed:

H3: Behavioral aspect has a positive influence on intention to use

\section{Intention to Use and Usage Behavior}

Intention is defined as actions that have a purpose regarding an objective (Ravi, Carr, \& Sagar, 2006). Keil, Beranek, \& Konsynski (1995) stated that intention is the power of behavior that consciously does something that has been previously targeted. Thus, the 
International Journal of Economics, Business and Accounting Research (IJEBAR)

Peer Reviewed - International Journal

Vol-4, Issue-1, 2020 (IJEBAR)

E-ISSN: 2614-1280 P-ISSN 2622-4771

https://jurnal.stie-aas.ac.id/index.php/IJEBAR

intention to use is the expected result of what is intended.

Ajzen (1991) assumed intention as something that can be demonstrated through factors that influence behavior such as indicating how much nit a person has to try or can indicate how much effort someone has in planning to use something. Furthermore, research conducted by Christino, Silva, Cardozo, de Pádua Carrieri, \& de Paiva Nunes (2019) suggested that aspects of behavior, facility conditions, habits and intention to use significantly influence usage behavior. Therefore, the following hypothesis is as follows:

H4: The intention to use has a positive influence on usage behavior.

\section{Research Methodology}

The inferential statistical analysis approach in this study is Partial Least Square (PLS) which is calculated using SmartPLS 3.0 software. PLS is Structural Equation Model (SEM) that experienced a shift from covariant-based to variant-based (Ghozali, 2015). PLS can be used to confirm a theory and can be used to build relationships that do not yet have a theoretical basis. The purpose of this study was to examine the predictive effect between latent variables (hedonic motivation, utilitarian motivation, behavioral aspects, intention to use and usage behavior).

PLS analysis is provided by evaluating two models namely the outer model and inner model. The measurement model is used to test the validity and reliability. While the structural model is used to show the specification of the relationship between latent variables, namely between exogenous variables and endogenous variables (Ghozali, 2015). The measurement model is provided by comparing the values of construct $R^{2}$ and measuring the value of $Q^{2}$. Next, hypothesis testing is performed using t-statistic values.

\section{Result And Discussion}

The development of technology, especially digital applications provides easier various financial transactions so that people do not need to use cash money transaction. This condition changes the habits of consumers when making payment transactions for both online and offline purchases.

This study involved 113 respondents consisting of adolescents who have digital money applications on their smartphones. The results showed that the respondents were dominated by female with the number of 73 persons $(64.60 \%)$ and the rest of $40(34.40 \%)$ persons are male. Based on the age of the respondents, the majority of respondents were 85 people $(75 \%)$ aged between 15-19 years, while the rest were aged 20-24 years as many as 28 people (25\%). The results of the characteristics of respondents also found that the application of OVO digital money is the most widely used by 77 respondents (68\%), GO-PAY as many as 28 respondents $(25 \%)$ and the rest use DANA and DOKU. Based on the intensity of using cashback promotions in a month, 72 respondents (64\%) use it 1-2 times (64\%) a month, while the other 28 respondents (25\%) use it 3-4 times (25\%) a month. Furthermore, 8 respondents $(7 \%)$ use more than 6 times a month and 5 other respondents $(4 \%)$ use 5-6 times a month.

The results of the characteristics of respondents who show the dominance of female respondents can indicate that female are more interested in using digital money applications because they are more price sensitive. The cashback promotion program offered by the application encourages female respondents to use it. In addition, the results show that OVO and GO-PAY are the most widely used that be occurred due to both applications used 
International Journal of Economics, Business and Accounting Research (IJEBAR)

Peer Reviewed - International Journal

Vol-4, Issue-1, 2020 (IJEBAR)

E-ISSN: 2614-1280 P-ISSN 2622-4771

https://jurnal.stie-aas.ac.id/index.php/IJEBAR

cashback promotion strategy higher than the other. This is consistent with the opinion of Lestari, Arsilan, \& Rachman (2019) which states that cashback promotions are mostly carried out by these two applications to attract consumers.

Reliability tests using Cronbach's Alpha and composite reliability (CR) values verified the internal consistency of the items. All variables have CR above 0.7 that mean meeting the criterion of strong reliability. Regarding validity, the factor loadings values of all items are above 0.7. The average variance extracted (AVE) values of all constructs are above 0.7. The results support the convergent validity of the measurement model.

The results of this study indicate that hedonic motivation has a positive effect on intention to use with an effect value of 0.238 and a T-statistic value of 2.069. This research illustrates that cashback promotion programs that are fun, entertaining, interesting and satisfying influence consumers to use digital money applications. The results of this study are supported by research conducted by Christino, Silva, Cardozo, de Pádua Carrieri, \& de Paiva Nunes (2019) which states that hedonic motivation influences one's intention to use the site due to a sense of fun when using the site. Furthermore, Ozturk, Nusair, Okumus, \& Hua (2016) also found that hedonic motivation is able to encourage someone to have an intention to make repeat purchases in the future

Table 1. Latent Variables Statistics

\begin{tabular}{llrll}
\hline Construct & Item & Loading & CR & AVE \\
\hline Hedonic & HED1 & 0.877 & 0.947 & 0.818 \\
& HED2 & 0.940 & & \\
& HED3 & 0.929 & & \\
Utilitarian & HED4 & 0.869 & & \\
& UTI1 & 0.808 & 0.902 & 0.755 \\
& UTI2 & 0.893 & & \\
Behavioral & UEH3 & 0.903 & & \\
Aspect & BEH2 & 0,874 & 0.902 & 0.767 \\
& BEH3 & 0,897 & & \\
Intention & INT1 & 0.900 & 0.920 & 0.794 \\
to Use & INT2 & 0.897 & & \\
& INT3 & 0.876 & & \\
Usage & UBE1 & 0.911 & 0.875 & 0.702 \\
Behavioral & UBE2 & 0.806 & & \\
& UBE3 & 0.791 & & \\
\hline
\end{tabular}

Table 2. Path Analysis

\begin{tabular}{lrrr}
\hline Hypothesis & Estimate & T-value & Yes/No \\
\hline HED $\rightarrow$ INT & 0.238 & 2.069 & Yes \\
UTI $\rightarrow$ INT & 0.329 & 2.741 & Yes \\
BEH $\rightarrow$ INT & 0.197 & 2.100 & Yes \\
INT $\rightarrow$ UBE & 0.670 & 10.693 & Yes \\
\hline
\end{tabular}

Furthermore, utilitarian motivation which illustrates motivation from its usefulness aspects also has a positive influence on intention to use with an effect of 0.329 and a T- 
International Journal of Economics, Business and Accounting Research (IJEBAR)

Peer Reviewed - International Journal

Vol-4, Issue-1, 2020 (IJEBAR)

E-ISSN: 2614-1280 P-ISSN 2622-4771

https://jurnal.stie-aas.ac.id/index.php/IJEBAR

statistic value of 2.741. Compared to hedonic motivation, it appears that utilitarian motivation tends to be more influence consumers' intention to use digital applications. This discovery could be due to consumers paying more attention to the utilitarian aspects of the benefits, truth and reliability of the application of digital money compared to the hedonic motivation that emphasizes the aesthetic and creativity aspects. Research conducted by Chen, Shang, \& $\mathrm{Li}$ (2014) which stated that utilitarian motivation often encourages a person to make a purchase intention as well as a repurchase intention in the future.

In addition to hedonic and utilitarian motivation, the results of the study also found that behavioral aspects have a positive influence on intention to use. The indicators that underlie these behavioral aspects are purchases that are more than usual, brand-switching and a description of store/product choices. This gives an indication that these indicators are encouraging consumers to have the intention to use. The cashback promotion program leads to brand shifting because of the promotion as a trigger for behavior change. However, the results of this study are not in line with research conducted by Christino, Silva, Cardozo, de Pádua Carrieri, \& de Paiva Nunes (2019) which states that aspects of behavior do not have a positive influence on intention to use.

Furthermore, the results of the study found that the intention to use has the strongest positive influence on usage behavior with a t-statistic value of 10.693 and an effect of 0.670 . It can be concluded that from the research model there is the highest influence found on the intention to use variables on usage behavior. These findings are in line with the results of the study put forward by Christino, Silva, Cardozo, de Pádua Carrieri, \& de Paiva Nunes (2019) that there is a positive influence of intention to use on usage behavior.

This study also shows the goodness of fit of the model is very strong. The variable of intention to use has $\mathrm{R}^{2}$ of 0.458 and usage behavioral has $\mathrm{R}^{2}$ of 0.449 . Based on this result, the value of $\mathrm{Q}^{2}$ can be provided by 0.701 . It means that the goodness of fit of this model is very strong.

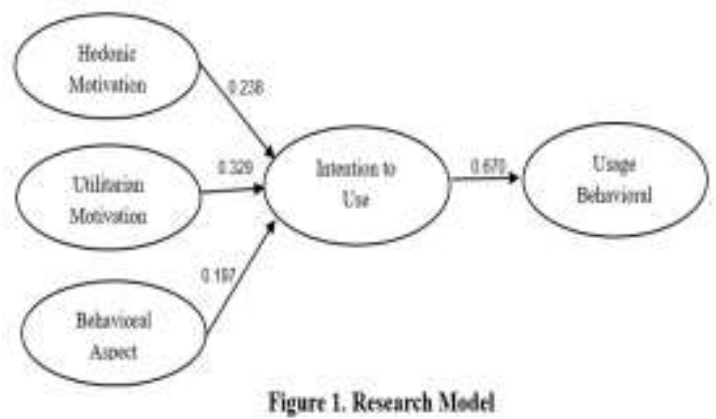

\section{Conclusion}

In general, understanding the behavior of using digital money in adolescents can be an opportunity on how companies need to implement their marketing strategies. Cashback promotion can be an effective marketing strategy for companies to attract consumers and win the market, especially with the target teen market.

This study uses several variables that focus on factors that influence consumers themselves, namely hedonic and utilitarian motivation, behavioral aspects, intention to use and usage behavior. The results of the study concluded that hedonic and utilitarian motivation, as well as behavioral aspects have a positive influence on intention to use. 
International Journal of Economics, Business and Accounting Research (IJEBAR)

Peer Reviewed - International Journal

Vol-4, Issue-1, 2020 (IJEBAR)

E-ISSN: 2614-1280 P-ISSN 2622-4771

https://jurnal.stie-aas.ac.id/index.php/IJEBAR

Furthermore, intention to use has a positive influence on usage behavior.

Based on the results of the study, the company needs to run a cashback promotion program to encourage brand switching and communication channel. In addition, in the product introduction stage, companies can apply this cashback promotion as an effective marketing strategy. Furthermore, companies also need to apply terms and conditions (T\&C) that are easily understood by consumers so that it encourages them to use the promotion.

This study has various limitations, so that in subsequent studies it can add convenience and risk perception variables to determine its relationship with usage behavior. Research can also be developed by expanding respondents from various generations because each generation can have different criteria in responding to a product promotion program.

\section{References}

Ajzen, I. (1991). The theory of planned behavior. Organizational Behavior and Human Decision Processes, 50(2), 179-211. https://doi.org/10.1016/0749-5978(91)90020-T

Anderson, K. C., Knight, D. K., Pookulangara, S., \& Josiam, B. (2014). Influence of hedonic and utilitarian motivations on retailer loyalty and purchase intention: A facebook perspective. Journal of Retailing and Consumer Services, 21(5), 773-779. https://doi.org/10.1016/j.jretconser.2014.05.007

Ballestar, M. T., Garu-Carles, P., \& Sainz, J. (2016). Consumer behavior on cashback websites: Network strategy. Journal of Business Research, 69.

Bilgihan, A., \& Bujisic, M. (2015). The effect of website features in online relationship marketing: A case of online hotel booking. Electronic Commerce Research and Applications, 14(4), 222-232. https://doi.org/10.1016/j.elerap.2014.09.001

Chen, Y. C., Shang, R. A., \& Li, M. J. (2014). The effects of perceived relevance of travel blogs' content on the behavioral intention to visit a tourist destination. Computers in Human Behavior, 30, 787-799. https://doi.org/10.1016/j.chb.2013.05.019

Christino, J. M. M., Silva, T. S., Cardozo, E. A. A., de Pádua Carrieri, A., \& de Paiva Nunes, P. (2019). Understanding affiliation to cashback programs: An emerging technique in an emerging country. Journal of Retailing and Consumer Services, 47(November 2018), 78-86. https://doi.org/10.1016/j.jretconser.2018.10.009

Ding, C. G., \& Tseng, T. H. (2015). On the relationships among brand experience, hedonic emotions, and brand equity. European Journal of Marketing, 49(7-8), 994-1015. https://doi.org/10.1108/EJM-04-2013-0200

Fajrina, N. H. (2016). No Title. Retrieved April 19, 2019, from CNN website: https://www.cnnindonesia.com/teknologi/20160419132814-185-124997/mengenalfintech-layanan-perbankan-berbasis-online

Jayabuana, N. N. (2018). Cashback Tarik Minat Masyarakat Berbelanja Daring. Retrieved from https://ekonomi.bisnis.com/read/20181008/12/846759/cashback-tarik-minatmasyarakat-berbelanja-daringuse

Keil, M., Beranek, P. M., \& Konsynski, B. R. (1995). Usefulness and ease of use: field study evidence regarding task considerations. Decision Support Systems, 13(1), 75-91. https://doi.org/10.1016/0167-9236(94)E0032-M

Lestari, D., Arsilan, R., \& Rachman, A. (2019). Sengitnya Perang Uang Electronik. Retrieved April 10, 2019, from https://www.msn.com/id-id/ekonomi/bisnis/sengitnya-peranguang-elektronik/ar-BBUyrpy

Lissitsa, S., \& Kol, O. (2016). Generation X vs. Generation Y - A decade of online shopping. 
International Journal of Economics, Business and Accounting Research (IJEBAR)

Peer Reviewed - International Journal

Vol-4, Issue-1, 2020 (IJEBAR)

E-ISSN: 2614-1280 P-ISSN 2622-4771

https://jurnal.stie-aas.ac.id/index.php/IJEBAR

Journal of Retailing and Consumer Services, 31, 304-312.

https://doi.org/10.1016/j.jretconser.2016.04.015

Morgan, R. M., \& Hunt, S. D. (1994). The Commitment-Trust Theory of. 58(July), 20-38.

Okada, E. M. (2005). Justification effects on consumer choice of hedonic and utilitarian goods. Journal of Marketing Research, 42(1), 43-53.

https://doi.org/10.1509/jmkr.42.1.43.56889

Overby, J. W., \& Lee, E. J. (2006). The effects of utilitarian and hedonic online shopping value on consumer preference and intentions. Journal of Business Research, 59(10-11), 1160-1166. https://doi.org/10.1016/j.jbusres.2006.03.008

Ozturk, A. B., Nusair, K., Okumus, F., \& Hua, N. (2016). The role of utilitarian and hedonic values on users' continued usage intention in a mobile hotel booking environment.

International Journal of Hospitality Management, 57, 106-115. https://doi.org/10.1016/j.ijhm.2016.06.007

Rachman, V. (2016). No Title. SWA Magazine. Retrieved from https://swa.co.id/swa/magazine-edition/gelombang-dahsyat-fintech-menyerbu-bisniskeuangan-majalah-swa-edisi-212016

Ravi, V., Carr, M., \& Sagar, N. V. (2006). Profiling of Internet Banking Users in India Using Intelligent Techniques. Journal of Services Research, 6(2), 61-73. Retrieved from http://search.ebscohost.com/login.aspx?direct=true \&db=bth\&AN=23654496\&site=ehos t-live

Scholl-Grissemann, U., \& Schnurr, B. (2016). Room with a view: how hedonic and utilitarian choice options of online travel agencies affect consumers' booking intentions.

International Journal of Culture, Tourism, and Hospitality Research, 10(4), 361-376. https://doi.org/10.1108/IJCTHR-06-2016-0062

To, P. L., Liao, C., \& Lin, T. H. (2007). Shopping motivations on Internet: A study based on utilitarian and hedonic value. Technovation, 27(12), 774-787.

https://doi.org/10.1016/j.technovation.2007.01.001

Vana, P., Lambrecht, A., \& Bertini, M. (2018). Cashback Is Cash Forward: Delaying a Discount to Entice Future Spending. Journal of Marketing Research, 55(6), 852-868. https://doi.org/10.1177/0022243718811853

Venkatesh, V., Thong, J. Y. L., \& Xu, X. (2016). Unified theory of acceptance and use of technology: A synthesis and the road ahead. Journal of the Association of Information Systems, 17(5), 328-376.

Zeithaml, V. A., Parasuraman, A., \& Malhotra, A. (2002). Service quality delivery through web sites: A critical review of extant knowledge. Journal of the Academy of Marketing Science, 30(4), 362-375. https://doi.org/10.1177/009207002236911

Zhou, Y. W., Cao, B., Tang, Q., \& Zhou, W. (2017). Pricing and rebate strategies for an eshop with a cashback website. European Journal of Operational Research, 262(1), 108122. https://doi.org/10.1016/j.ejor.2017.03.037 